\title{
Wpływ środków regulujących czas wiązania na parametry reologiczne zaczynu cementowego
}

\begin{abstract}
W artykule przedstawiono wpływ środków regulujących czas wiązania na parametry reologiczne zaczynu cementowego. Dodatek lignosulfonianów stosowany jest do wydłużenia czasu wiązania zaczynu cementowego. Środek ten wykorzystuje się przy projektowaniu zaczynów przeznaczonych do uszczelniania kolumn rur okładzinowych posadowionych na znacznych głębokościach, gdzie występuje wysoka temperatura na dnie otworu. Wskutek podwyższonej temperatury hydratacja zaczynu cementowego przebiega znacznie szybciej, co wymusza stosowanie dodatków wydłużających czas wiązania w celu bezpiecznego wtłoczenia zaczynu $\mathrm{w}$ uszczelnianą przestrzeń pierścieniową i pozarurową. Z kolei do skrócenia czasu wiązania zaczynu cementowego najczęściej wykorzystywanym środkiem przyspieszającym jest chlorek wapnia. Czas wiązania wymaga skrócenia z uwagi na względy ekonomiczno-technologiczne, począwszy od skrócenia czasu potrzebnego na wiązanie zaczynu i przejścia do dalszych prac wiertniczych, a skończywszy na wyeliminowaniu ewentualności wtargnięcia medium gazowego w strukturę wiążącego zaczynu cementowego. Stosowanie dodatków regulujących czas wiązania zaczynu cementowego nie pozostaje bez znaczenia dla jego parametrów reologicznych. Podczas realizowanych prac badawczych, których celem było określenie wpływu opóźniaczy i przyspieszaczy na parametry reologiczne zaczynu, wykorzystano dodatek lignosulfonianu (opóźniacza) w ilości od $0,1 \%$ do $0,3 \%\left(\right.$ bwoc $^{1}$ ) oraz dodatek chlorku wapnia (przyspieszacza) w ilościach od $1 \%$ do 3\% (bwoc). Następnie wykonano badania podstawowych parametrów technologicznych zaczynów cementowych, badania parametrów reologicznych, wyznaczono określone modele reologiczne, wykreślono krzywe płynięcia i na podstawie uzyskanych danych omówiono wpływ stosowania wytypowanych dodatków na parametry reologiczne zaczynu cementowego.
\end{abstract}

Słowa kluczowe: zaczyn cementowy, parametry mechaniczne, przyspieszacz wiązania, opóźniacz wiązania, wiązanie zaczynu, parametry reologiczne, lepkość plastyczna, granica płynięcia, lignosulfonian, chlorek sodu.

\section{Effect of agents regulating the setting time on rheological parameters of cement slurry}

The article presents the impact of measures to regulate the setting time on the rheological parameters of cement slurry. The addition of lignosulfonates is used to extend the setting time of cement paste. This agent is used in the design of cement slurries intended for sealing casing pipe columns set at considerable depths, where there is a high temperature at the bottom of the hole. Due to the elevated temperature, the hydration of the cement paste proceeds much faster, which forces the use of additives that extend the setting time to safely enter the grout into the sealed annular and non-annular space. On the other hand, in order to reduce the bonding time of cement paste, the most commonly used accelerator is calcium chloride. The setting time requires shortening due to economic and technological considerations, ranging from the shortening of the time needed to set the grout and the transition to further drilling work, ending with the elimination of the possibility of gaseous medium intrusion into the binding cement slurry. The use of additives regulating the setting time of cement paste is not without significance for its rheological parameters. During the research work aimed at determining the influence of retarders and accelerators on the rheological parameters of the slurry, the addition of lignosulfonate (retarder) in an amount of 0.1 to $0.3 \%$ (bwoc), and calcium chloride (accelerator) in quantities from 1 to 3\% (bwoc) were used. Then, the basic technological parameters of cement slurries were tested, rheological parameters were examined, specific rheological models were determined, flow curves were plotted and based on the obtained data the effect of using selected additives on rheological parameters of cement paste was discussed.

Key words: cement slurry, mechanical parameters, binding accelerator, setting retarder, spout binding, rheological parameters, viscosity, yield point, lignosulphonate, sodium chloride.

${ }^{1}$ bwoc (z ang. by weight of cement) - w stosunku do masy cementu 


\section{Wprowadzenie}

Podczas projektowania receptury zaczynu przeznaczonego do uszczelniania kolumn rur okładzinowych posadowionych w określonych strukturach geologicznych dobierane są odpowiednie parametry technologiczne zaczynu. Głównym celem zabiegu cementowania jest maksymalne wypełnienie przestrzeni pierścieniowej lub pozarurowej, szczelne zaizolowanie stref przepuszczalnych oraz ustabilizowanie kolumny rur okładzinowych. Projektowany zaczyn cementowy musi spełniać szereg wymagań określonych w odpowiednich normach oraz być dostosowany do warunków geologiczno-technicznych. W tym celu stosuje się różnego rodzaju dodatki i domieszki do zaczynów, umożliwiające regulowanie określonych parametrów. Jednym z konstytutywnych parametrów określanych w projektowanym zaczynie cementowym jest jego czas wiązania. Odpowiednio zaprojektowany zaczyn cementowy powinien zachowywać przetłaczalność przez cały czas potrzebny do wytłoczenia go do przestrzeni pierścieniowej. Czas ten powinien być powiększony o margines bezpieczeństwa $\mathrm{w}$ razie nieprzewidzianych sytuacji wymagających dodatkowych prac w trakcie cementowania [34]. Odpowiednio zaprojektowana receptura zaczynu cementowego powinna charakteryzować się wiązaniem następującym niedługo po wpompowaniu zaczynu w uszczelniany interwał. Zaczyn cementowy powinien posiadać takie parametry reologiczne, przy których możliwe będzie skuteczne wypieranie płuczki i cieczy buforowej z otworu przy zachowaniu jak najmniejszych oporów przepływu [4], posiadać odpowiednią gęstość, być stabilny pod względem sedymentacyjnym, nie wykazywać odstoju wody oraz posiadać filtrację w warunkach HPHT zgodną z wartością ustaloną $\mathrm{w}$ projekcie cementowania. Jednakże $\mathrm{w}$ dobieraniu parametrów zaczynu cementowego głównym warunkiem jest odpowiednio dopasowany czas wiązania do danych warunków geologiczno-technicznych przy jednoczesnym zachowaniu wymaganych wartości pozostałych parametrów projektowanej receptury $[9,12]$. Środki służące do regulacji czasu wiązania niejednokrotnie wpływają na zmianę lepkości zaczynu, co nie jest bez znaczenia podczas analizy efektywności uszczelniania w aspekcie przetłaczalności zaczynu. Dlatego też w niniejszej publikacji poruszono zagadnienie dotyczące wpływu dodatków regulujących czas wiązania na parametry reologiczne zaczynu cementowego.

\section{Dobór odpowiedniego czasu wiązania zaczynu cementowego}

Podczas projektowania receptury zaczynu cementowego przeznaczonego do uszczelniania kolumny rur okładzinowych w określonych warunkach geologiczno-technicznych czas wiązania regulowany jest za pomocą odpowiednich dodatków, określanych mianem przyspieszaczy i opóźniaczy.

W celu skrócenia czasu wiązania dodawane są przyspieszacze wiązania cementu [19]. Czas wiązania zaczynu skraca się z powodu dostosowania go do warunków geologicz- no-technicznych, w celu wyeliminowania zbędnego przestoju na wiązanie cementu, a przede wszystkim z uwagi na zniwelowanie wydłużającego (czas wiązania) działania innych chemikaliów stosowanych w recepturze zaczynu w celu uzyskania wymaganych wartości pozostałych parametrów zaczynów [20]. Najczęściej takie działanie wydłużające czas wiązania zaczynu obserwowane jest przy wykorzystywaniu dodatków dyspergujących i środków na obniżenie filtracji zaczynu.

\section{Środki wydłużające czas wiązania i mechanizm ich działania}

W celu wydłużenia czasu wiązania zaczynu cementowego stosuje się dodatki określane mianem opóźniaczy wiązania. Sposób działania środków tego rodzaju jest przedmiotem ciągłych rozważań. Istnieje wiele teorii dotyczących mechanizmu wydłużania czasu wiązania, ale żadna $\mathrm{z}$ nich w pełni nie wyjaśnia tego procesu. Najczęściej przyjmuje się dwa podstawowe czynniki: pierwszym jest chemiczna natura opóźniacza, a drugim glinowa lub krzemianowa faza cementu, na którą wpływa opóźniacz. Istnieją cztery podstawowe teorie [19], które niejako thumaczą działanie opóźniające środków wydłużających czas wiązania.

Pierwszą z nich jest teoria adsorpcji, która przedstawia opóźnianie wiązania poprzez adsorpcję środka opóźniające- go na powierzchni produktów wytworzonych w procesie hydratacji, co utrudnia ich kontakt z wodą. Druga to teoria wytrącania, która sugeruje, że dodatek opóźniający reaguje z wapieniem lub jonami hydroksylu jeszcze w fazie wodnej, tworząc wokół ziaren nierozpuszczalną i nieprzepuszczalną warstwę. Teoria krystalizacji jest trzecią teorią i mówi, że środek opóźniający adsorbuje na kryształkach produktów hydratacji, przez co opóźnia lub nawet niszczy ich dalszy rozrost. Czwarta teoria to zespalanie, w wyniku którego opóźniacz powoduje żelatację jonów wapnia i tym samym przeciwdziała tworzeniu się kryształków [19]. Na podstawie rozpoznania literaturowego uważa się, że wszystkie powyższe teorie są w różnym stopniu zaangażowane w proces opóźniania reakcji wiązania cementu. 
Najbardziej znanymi dodatkami opóźniającymi wiązanie cementu portlandzkiego są sole wapnia i sodu kwasów lignosulfonianowych, określane mianem lignosulfonianów (rysunek 1). Są to polimery otrzymywane z pulpy drzewnej i często występują w formie nierafinowanej zawierającej dużo komponentów cukrowych [19]. Środki te są bardzo efektywne i wykorzystuje się je w ilościach od $0,1 \%$ do $1,5 \%$ w stosunku do masy cementu (bwoc), a ich temperaturowy zakres stosowalności wynosi około $122^{\circ} \mathrm{C}$. Odporność na działanie wysokich temperatur zaczynów z dodatkiem lignosulfonianów można zwiększyć za pomocą dodatku boraksu, wówczas temperaturowy zakres stosowalności zostanie podwyższony do około $315^{\circ} \mathrm{C}$. Mechanizm opóźniania lignosulfonianów oparty jest na teorii adsorpcji (wodoodporne działanie zaadsorbowanych lignosulfonianów przerywa dalszą hydratację [6]) i krystalizacji (lignosulfoniany połączone $\mathrm{z}$ jonami wapnia za pomocą sił elektrostatycznych powodują zatrzymanie krystalizacji wodorotlenku wapnia [5]).

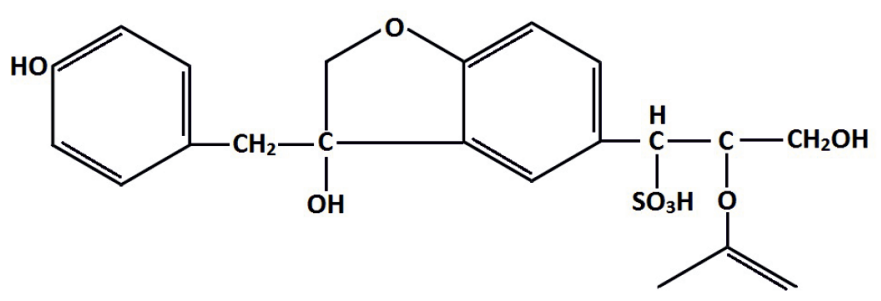

Rys. 1. Podstawowa struktura chemiczna lignosulfonianów

Innym rodzajem środków opóźniających wiązanie są kwasy karboksylowe. Zawierają one w swoich molekularnych strukturach hydroksyl i karboksyl. Obecne w strukturze kwasów karboksylowych sole glikonianowe i glikoheptonowe (rysunek 2) wykazują bardzo mocne działanie opóźniające wiązanie w temperaturach do $150^{\circ} \mathrm{C}$ [19]. Do tej grupy środków należy również kwas cytrynowy, którego efektywna koncentracja w stosunku do masy cementu zawarta jest w przedziale od $0,1 \%$ do $0,3 \%$ [19]. Analizując mechanizm działania opóźniającego kwasów hydroksykarboksylowych oraz ich soli, efekt wydłużenia czasu wiązania tłumaczyć można formowaniem wysoko stabilnych pięciu lub sześciu pierścieni adsorbujących na powierzchni uwodnionego cementu, w wyniku czego następuje opóźnienie krystalizacji produktów hydratacji [19].

Następnym rodzajem środków opóźniających wiązanie cementu są komponenty cukrowe. Cukry są bardzo dobrze znanymi opóźniaczami (głównie pięciopierścieniowe środki znane pod nazwami sukroza i rafinoza) [2], jednakże z uwagi na ich zmienne działanie dodatki cukrowe nie są stosowane. Mechanizm działania cukrów opiera się na teorii adsorpcji. Podczas transformacji cukrów na kwasy sacharydowe, które za-

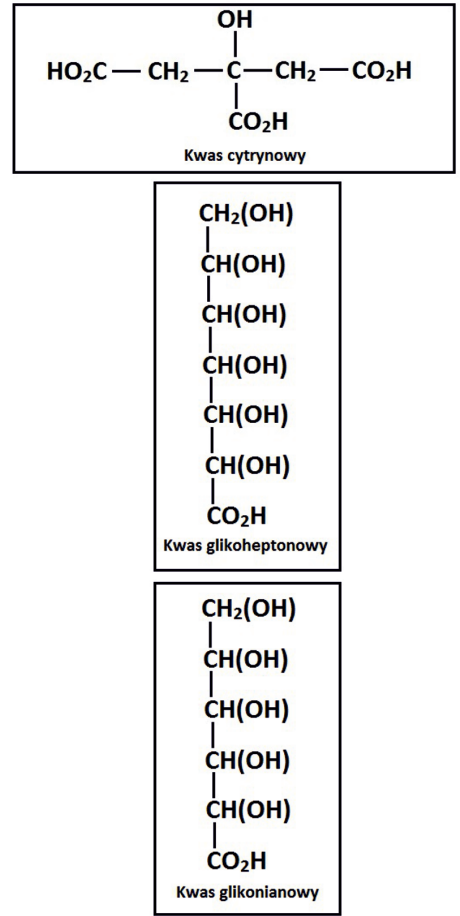

Rys. 2. Struktura molekularna kwasu hydroksykarboksylowego

wierają grupy alfa i beta $\mathrm{HO}-\mathrm{C}-\mathrm{C}=\mathrm{O}$, adsorbują się one na powierzchniach żelowych C-S-H [29]. Zatrzymanie hydratacji cementu spowodowane jest adsorpcją amonową kwasów cukrowych [18].

W celu opóźnienia czasu wiązania zaczynów cementowych stosować można również pochodne celulozy, czyli polisacharydy otrzymywane $z$ drewna lub innych roślin. Mechanizm działania tego typu środków polega na adsorpcji polimerów na uwodnionej powierzchni cementu. Stroną aktywną w tego rodzaju procesie są ogniwa tlenku etylenu i grup karboksylowych [19].

Mniej znanymi środkami, ale również posiadającymi możliwość wydłużenia czasu wiązania spoiw hydraulicznych są fosforany organiczne. Kwasy alkilowo-fosforanowe oraz ich sole mogą być stosowane jako opóźniacze wiązania [19]. Mechanizm ich działania polega na tym, że grupy fosforowe adsorbują się na uwodnionych powierzchniach cementów, podobnie jak dzieje się to w przypadku innych rodzajów środków opóźniających [19].

Konkludując, można stwierdzić, że wydłużanie czasu wiązania zaczynu cementowego wiąże się głównie $\mathrm{z}$ adsorpcją części środków opóźniających na elementach hydratyzującego cementu. Wskutek powyższego środki opóźniające zmniejszają dostęp wody potrzebnej do hydratacji cementu i tym samym następuje ograniczenie lub zatrzymanie budowania fazy C-S-H i narastania kryształów $[7,14]$. Takie działanie dodatków opóźniających nie pozostaje bez znaczenia dla parametrów reologicznych zaczynu cementowego, co zostało omówione w dalszej części niniejszej publikacji. 


\section{Środki skracające czas wiązania i mechanizm ich działania}

Najczęściej stosowanymi dodatkami do skrócenia czasu wiązania cementów portlandzkich są sole nieorganiczne, najczęściej chlorki. Literatura $[7,19]$ podaje również informację o wykorzystaniu jako przyspieszacza wiązania dodatków soli węglanowych, krzemianowych (głównie sodu), glinowych, azotanowych, siarczkowych. Stosuje się również dodatki wodorotlenków sodu, potasu oraz niekiedy amonu. Analizując działanie przyspieszające dodatków chlorków, zaobserwowano wzrost skuteczności skracania czasu wiązania wraz ze wzrostem wartościowości chlorków (od jednowartościowych do trójwartościowych) [23]. Analizując powyższe, przyjmuje się, że chlorek wapnia jest najbardziej wydajnym i jednocześnie stosunkowo ekonomicznym przyspieszaczem. Zazwyczaj $\mathrm{CaCl}_{2}$ stosuje się w ilościach od $2 \%$ do $4 \%$ w stosunku do masy cementu (bwoc). Stężenia większe od 6\% uniemożliwiają wychwycenie efektu działania, ponieważ wiązanie następuje przedwcześnie i może być obserwowane nawet na etapie wytłaczania cementu [19]. Działanie przyspieszające chlorku wapnia jest wprost proporcjonalne do stosowanej ilości, co nie jest takie oczywiste, ponieważ drugi rodzaj przyspieszacza, chlorek sodu, działa w nieco inny sposób. Jego działanie zależy od koncentracji oraz od temperatury, co ilustruje rysunek 3. Działanie przyspieszające chlorku sodu obserwowane jest do koncentracji $10 \% \mathrm{w}$ stosunku do ilości wody zarobowej (bwow). W zakresie od 10\% do $18 \%$ bwow chlorek sodu nie wykazuje żadnego działania, natomiast koncentracja powyżej $18 \%$ bwow powoduje opóźnianie czasu wiązania. $\mathrm{NaCl}$ nie jest efektywnym przyspieszaczem, jednakże podczas wierceń na morzu i stosowania wody morskiej jako wody zarobowej, w której koncentracja $\mathrm{NaCl}$ wynosi około $25 \mathrm{~g} / \mathrm{dm}^{3}$, działanie chlorku sodu uważane jest jako dodatek środka przyspieszającego wiązanie zaczynu (2,5\% bwow).

$\mathrm{Z}$ uwagi na wspomniane zróżnicowanie w działaniu $\mathrm{NaCl}$ do skrócenia czasu wiązania najczęściej stosuje się chlorek wapnia, którego mechanizm działania jest skomplikowany i ciągle nie do końca poznany. Istnieje szereg hipotez dotyczących działania skracającego czas wiązania zaczynu za pomocą chlorku wapnia. Według $[1,29]$ reakcja przyspieszania wiązania wynika ze wzrostu poziomu hydratacji systemu tlenek glinu - gips. Jony chlorku aktywują tworzenie się ettringitu do czasu, kiedy jest gips. Jeżeli $\mathrm{C}_{3} \mathrm{~A}$ jest w stanie wolnym, to tworzy się $\mathrm{C}_{3} \mathrm{~A} \cdot \mathrm{CaCl}_{2} \cdot 10 \mathrm{H}_{2} \mathrm{O}$. Wzrost szybkości wiązania cementu w kolejnych etapach wiąże się z wystąpieniem krystalicznej fazy ettringitu w formie igiełek $[1,33]$. Działanie skracające czas wiązania znajduje potwierdzenie w badaniach procesu hydratacji i czystej fazy krzemionkowej $\mathrm{C}_{3} \mathrm{~S}$ $\mathrm{i}_{2} \mathrm{~S}$ opublikowanych w [21]. Z kolei w publikacji [17] czytamy, że chlorek wapnia wywiera znaczny wpływ na dystrybucję jonów w zaczynie, który jest jeszcze w fazie wodnej. Jony $\mathrm{Ca}^{2+}$, które nie biorą udziału w formowaniu produktów hydratacji, powodują zmniejszenie koncentracji hydroksylu i siarczanów oraz wzrost koncentracji wapnia. Na podstawie powyższego wysnuto tezę, że działanie przyspieszające chlorku wapnia wiąże się z obniżeniem alkaliczności fazy uwodnionej, a tym samym ze wzrostem stopnia rozpuszczalności wapnia [15]. Podsumowując powyższe rozważania, można stwierdzić, że na proces przyspieszonego wiązania cementu w obecności chlorku wapnia wpływ ma wiele czynników jednocześnie, a zjawiska chemiczne i fizyczne odgrywają zróżnicowane role.

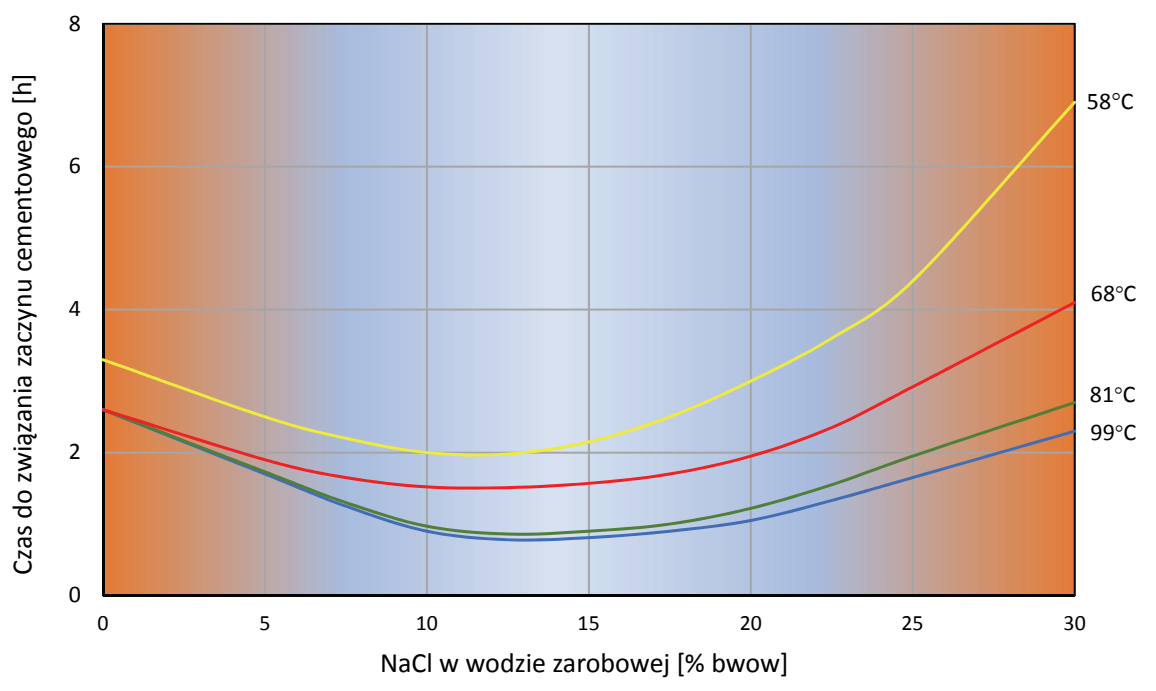

Rys. 3. Wpływ chlorku sodu na wiązanie zaczynu cementowego

Dodatkowo należy wspomnieć, że zgodnie z publikacjami $[3,11]$ dodatek chlorku wapnia powoduje wzrost wytrzymałości strukturalnej cementu, ale jednocześnie nie prowadzi do wzrostu wartości lepkości plastycznej. Lepkość plastyczna zaczyna rosnąc dopiero po 30 minutach hydratacji w warunkach otoczenia. Ponadto zaczyny z dodatkiem chlorku wapnia oprócz podwyższonej wytrzymałości strukturalnej wykazują również tendencję do zwiększonego stopnia tiksotropii. Jest to korzystne z punktu widzenia podwyższonej stabilności sedymentacyjnej. Na temat wpływu dodatku chlorku wapnia w aspekcie reologii zaczynu nie ma zbyt wielu publikacji, w związku z czym w poniższej części przedstawiono badania obejmujące to zagadnienie. 


\section{Własności reologiczne zaczynu cementowego}

Poprawny dobór parametrów reologicznych zaczynu cementowego umożliwia skuteczne wykonanie zabiegu cementowania rur okładzinowych. Jest to niezbędne do uzyskania możliwie maksymalnego wyparcia płuczki z przestrzeni pierścieniowej w trakcie zabiegu cementowania. W tym celu należy zapewnić określoną prędkość przepływu w trakcie tłoczenia zaczynu, a to $\mathrm{z}$ kolei wiąże się z potrzebą regulowania jego parametrów reologicznych za pomocą specjalnego rodzaju środków polimerowych [10, 19, 25, 26, 30]. Zasada działania tego rodzaju dodatków polega głównie na częściowym zobojętnianiu ładunków elektrycznych na powierzchni ziaren cementu. Wynikiem powyższego jest zwiększenie ruchliwości ziaren i tym samym płynności zaczynu [13, 27]. Regulowania parametrów reologicznych można również dokonać poprzez zmianę sił tarcia wewnętrznego cząsteczek zaczynu, co jest możliwe do uzyskania wskutek efektu sferycznego bądź elektrostatycznego, polegającego na odpychaniu zjonizowanych grup sulfonowych [16, 24, 27, 31]. Obecność grup sulfonowych $-\mathrm{SO}_{3} \mathrm{H}$ znajduje zastosowanie zarówno w środkach upłynniających, jak też w środkach opóźniających czas wiązania zaczynu, jednakże mechanizm działania jest zróżnico- wany w zależności od pozostałych grup funkcyjnych. Z kolei obecność środków przyspieszających wiązanie zaczynu, tj. chlorku wapnia, powoduje wzrost parametrów reologicznych tłoczonego zaczynu, co uniemożliwia uzyskanie turbulentnego przepływu lub wymaga zastosowania wysokich wydajności pomp dla przepływu o wartości liczby Reynoldsa $>3000$. Takie przepływy są niezbędne w celu dokładnego usunięcia płuczki z wypełnianej przestrzeni pierścieniowej. Jednak nadmierny wzrost wydatku tłoczenia w przypadku zaczynu o wysokich wartościach parametrów reologicznych może skutkować podwyższonym ryzykiem rozszczelinowania złoża $[8,22,32]$.

Na podstawie powyższego stwierdza się, że parametry reologiczne opracowywanego zaczynu w znaczący sposób wpływają na efektywność uszczelnienia przestrzeni pierścieniowej i pozarurowej. Natomiast odpowiednio dobrany czas wiązania zaczynu jest wymagany do sprawnego przeprowadzenia zabiegu cementowania oraz wyeliminowania ewentualności pojawienia się mikroprzepływów lub migracji po związaniu płaszcza cementowego. W związku z powyższym w artykule omówiono wpływ dodatków regulujących czas wiązania na parametry reologiczne zaczynu.

\section{Przebieg prac badawczych}

Badania mające na celu określenie wpływu dodatków regulujących czas wiązania na parametry reologiczne zaczynu cementowego przeprowadzono w Laboratorium Zaczynów Uszczelniających INiG - PIB na podstawie norm: PN-85/G-02320 Cementy i zaczyny cementowe do cementowania w otworach wiertniczych; PN-EN 10426-2 Przemyst naftowy i gazowniczy. Cementy i materiaty do cementowania otworów. Część 2: Badania cementów wiertniczych oraz API SPEC 10 Specification for materials and testing for well cements.

Zaprezentowany w niniejszej publikacji cykl badawczy polegał na wykazaniu wpływu dodatku środków regulujących czas wiązania na parametry reologiczne zaczynu cementowego. Jako przyspieszacz wiązania zaczynu cementowego zastosowano chlorek wapnia, natomiast wydłużenie czasu wiązania uzyskano, działając na zaczyn dodatkiem opóźniacza na bazie lignosulfonianów.

Badania parametrów reologicznych oparte były na określeniu modelu reologicznego zaczynów uszczelniających, czyli dopasowaniu krzywej reologicznej, która najlepiej opisywała wyniki pomiarów w układzie współrzędnych: naprężenia styczne $(\tau)$ - szybkość ścinania $(\gamma)[25,27]$. Obliczenia wykonano za pomocą modelu matematycznego dopasowanego do krzywych płynięcia cieczy wiertniczych.
W celu określenia wpływu dodatków regulujących czas wiązania na parametry reologiczne zaczynów cementowych badaniom poddano w sumie osiem receptur. Sporządzone zostały dwie receptury kontrolne ( $\mathrm{nr} 1 \mathrm{i}$ nr 5), służące do wyznaczenia punktów odniesienia. Poddanymi badaniom zaczynami były receptury oznaczone numerami od 2 do 4 dla składów $\mathrm{z}$ dodatkiem środka przyspieszającego, którym był chlorek wapnia, oraz receptury oznaczone numerami od 6 do $8 \mathrm{z}$ dodatkiem środka opóźniającego, którym był opóźniacz na bazie lignosulfonianu. W celu określenia wpływu dodatków regulujących czas wiązania zastosowano zróżnicowane (wzrastające) ilości wytypowanych dodatków. Takie działanie pozwalało na dokładniejsze wychwycenie zmian zachodzących pod wpływem dawkowanego do zaczynu środka regulującego czas wiązania. Podczas realizowanych prac badawczych, w których głównym tematem dyskusji były dodatki regulujące czas wiązania oraz parametry reologiczne zaczynu, sporządzono nieskomplikowaną recepturę. W składzie zaczynu obecny był dodatek odpieniający w ilości $0,3 \%$ (bwoc), dodatek antyfiltracyjny w ilości $0,15 \%$ (bwoc) oraz dodatek upłynniający w ilości $0,2 \%$ (bwoc). W pierwszej grupie zaczynów (tablica 1) zastosowano od $0,1 \%$ (bwoc) do $0,3 \%$ (bwoc) dodatku lignosulfonianiu w celu opóźnienia czasu wiązania, natomiast w drugiej grupie zaczynów (tablica 2) użyto od 1\% do 
$3 \%$ dodatku chlorku wapnia, stosowanego jako przyspieszacz wiązania. Wszystkie receptury zaczynów sporządzono na bazie wody wodociągowej. Spoiwem wiążącym był cement portlandzki klasy CEM I 32,5R.

Receptury zaczynów oraz ilościowe zawartości poszczególnych dodatków i domieszek zestawiono w tablicach 1 oraz 2. W tablicy 3 przedstawiono otrzymane wyniki badań gęstości zaczynu, czasu wiązania oraz odczyty $\mathrm{z}$ aparatu $\mathrm{w}$ jednostkach fann przy 12 zakresach prędkości obrotowych od $600 \mathrm{obr} / \mathrm{min}$ do $1 \mathrm{obr} / \mathrm{min}$, co odpowiada prędkościom ścinania od 1022,040 do $1,703 \mathrm{~s}^{-1}$. Natomiast w tablicy 4 zestawione zostały parametry reologiczne badanych zaczynów opisywane według zestawionych modeli reologicznych.

Analizując uzyskane wyniki badań, stwierdzono, że dodatek lignosulfonianu stosowanego w celu opóźnienia czasu wiązania nie wykazywał wpływu na gęstość zaczynu. Wykorzystywany do przyspieszenia wiązania dodatek chlorku wapnia spowodował nieznaczny wzrost gęstości zaczynu (z $1830 \mathrm{~kg} / \mathrm{m}^{3}$ do $1835 \mathrm{~kg} / \mathrm{m}^{3}$ ) (tablica 3). Działanie takie może być wynikiem podwyższonej wodożądności chlorku wapnia, a także masą samego dodatku, który zastosowano w ilościach od 1\% do 3\%. Może to powodować nieznaczny wzrost masy zaczynu cementowego $\mathrm{w}$ jednostce objętości.
Wprowadzenie dodatku środka opóźniającego do receptury powodowało wydłużenie czasu początku wiązania z wartości 3 godz. 10 min w przypadku zaczynu bazowego $\mathrm{nr} 1$ do 5 godz. 20 min po zastosowaniu $0,3 \%$ (bwoc) dodatku lignosulfonianiu dla zaczynu $\mathrm{nr} 4$. Wzrost czasu początku wiązania był proporcjonalny do wzrostu ilości stosowanego opóźniacza w zakresie od $0,1 \%$ do $0,3 \%$. Również czas końca wiązania wzrastał wraz ze zwiększaniem ilości opóźniacza. Zaczyn bazowy (nr 1) osiągnął wartość końca wiązania (KW) po czasie 5 godz. 40 min, natomiast po zastosowaniu największej z badanych ilości lignosulfonianu ( $0,3 \%$ bwow) wartość $\mathrm{KW}$ osiągnięto po czasie 8 godz. 30 min (zaczyn nr 4). Uzyskane wyniki badań czasu wiązania zamieszczono w tabeli 3 oraz na rysunku 4.

Dodatek chlorku wapnia w zaczynach nr 6,7 i 8 zastosowanego $\mathrm{w}$ ilościach od $1 \%$ do $3 \%$ (bwoc) powodował skrócenie czasu początku wiązania (PW) z wartości wynoszącej 3 godz. 10 min dla zaczynu bazowego (nr 5) do 50 min po zastosowaniu $3 \% \mathrm{CaCl}_{2}$ w przypadku zaczynu $\mathrm{nr} 8$. Również czas końca wiązania uległ znacznemu skróceniu - z wartości wynoszącej 5 godz. 40 min dla zaczynu bazowego (nr 5) do wartości równej 4 godz. po zastosowaniu 3\% chlorku wapnia w zaczynie nr 8. Uzyskane wyniki badań czasu początku i końca wiązania zamieszczono w tablicy 3 oraz na rysunku 4 .

Tablica 1. Receptury zaczynów cementowych z dodatkiem środka opóźniającego wiązanie (składniki stałe): cement CEM I 32,5R $=100 \%$

\begin{tabular}{|c|c|c|c|c|c|c|}
\hline $\begin{array}{c}\text { Skład (nr) } \\
\text { współczynnik (w/c) }\end{array}$ & $\begin{array}{c}\text { Dodatek } \\
\text { odpieniający }\end{array}$ & $\begin{array}{c}\text { Dodatek } \\
\text { antyfiltracyjny }\end{array}$ & \multicolumn{2}{|c|}{$\begin{array}{c}\text { Dodatek } \\
\text { upłynniający }\end{array}$} & \multicolumn{3}{|c|}{ Dodatek opóźniający wiązanie lignosulfonian } \\
(bwoc)
\end{tabular}

Tablica 2. Receptury zaczynów cementowych z dodatkiem środka przyspieszającego wiązanie (składniki stałe): cement CEM I 32,5R $=100 \%$

\begin{tabular}{|c|c|c|c|c|c|c|}
\hline $\begin{array}{c}\text { Skład (nr) } \\
\text { współczynnik (w/c) }\end{array}$ & $\begin{array}{c}\text { Dodatek } \\
\text { odpieniający }\end{array}$ & $\begin{array}{c}\text { Dodatek } \\
\text { antyfiltracyjny }\end{array}$ & \multicolumn{2}{|c|}{$\begin{array}{c}\text { Dodatek } \\
\text { upłynniający }\end{array}$} & \multicolumn{2}{|c|}{ Dodatek przyspieszający wiązanie CaCl } \\
(bwoc)
\end{tabular}


Tablica 3. Parametry zaczynów cementowych

\begin{tabular}{|c|c|c|c|c|c|c|c|c|c|c|c|c|c|c|c|c|c|}
\hline \multirow[b]{2}{*}{ 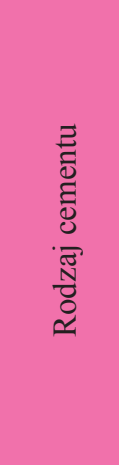 } & \multirow[b]{2}{*}{ 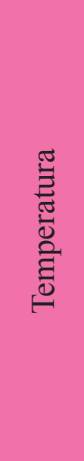 } & \multirow[b]{2}{*}{ 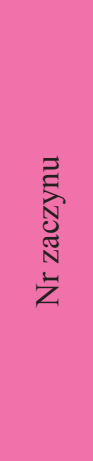 } & \multirow[b]{2}{*}{ 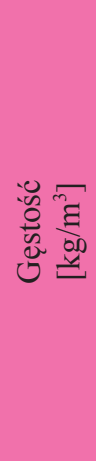 } & \multicolumn{2}{|c|}{$\begin{array}{l}\text { Czas wiązania } \\
\text { zaczynu w warun- } \\
\text { kach statycznych }\end{array}$} & \multicolumn{12}{|c|}{$\begin{array}{c}\text { Odczyty z aparatu Fann } \\
{[\mathrm{obr} / \mathrm{min}]}\end{array}$} \\
\hline & & & & 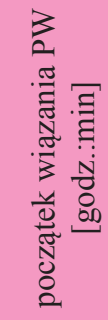 & 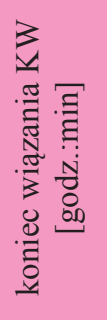 & 600 & 300 & 200 & 100 & 60 & 30 & 20 & 10 & 6 & 3 & 2 & 1 \\
\hline \multirow{8}{*}{$\begin{array}{l}\text { Cement } \\
\text { CEM I } \\
32,5 \mathrm{R}\end{array}$} & \multirow{8}{*}{$25^{\circ} \mathrm{C}$} & $1 \mathrm{baz}$ & 1830 & $3: 10$ & $5: 40$ & 172 & 95 & 68 & 39 & 26 & 16 & 13 & 9 & 7 & 6 & 6 & 5 \\
\hline & & 2 & 1830 & $3: 30$ & $7: 20$ & 150 & 78 & 55 & 30 & 19 & 11 & 8 & 5 & 4 & 2 & 2 & 1 \\
\hline & & 3 & 1830 & $4: 20$ & $8: 15$ & 145 & 79 & 56 & 30 & 20 & 11 & 8 & 5 & 4 & 2 & 2 & 2 \\
\hline & & 4 & 1830 & $5: 20$ & $9: 45$ & 136 & 72 & 50 & 28 & 18 & 11 & 8 & 5 & 3 & 3 & 2 & 2 \\
\hline & & $5 \mathrm{baz}$ & 1830 & $3: 10$ & $5: 40$ & 172 & 95 & 68 & 39 & 26 & 16 & 13 & 9 & 7 & 6 & 6 & 5 \\
\hline & & 6 & 1835 & $2: 40$ & $5: 10$ & 178 & 103 & 78 & 50 & 38 & 28 & 25 & 19 & 18 & 15 & 14 & 10 \\
\hline & & 7 & 1835 & $2: 10$ & $4: 40$ & 188 & 114 & 87 & 57 & 44 & 33 & 29 & 24 & 22 & 17 & 14 & 12 \\
\hline & & 8 & 1835 & $0: 50$ & $4: 00$ & 208 & 121 & 93 & 66 & 56 & 45 & 41 & 34 & 28 & 19 & 16 & 14 \\
\hline
\end{tabular}

Tablica 4. Parametry reologiczne zaczynów cementowych

\begin{tabular}{|c|c|c|c|c|c|c|c|c|c|}
\hline \multirow{2}{*}{$\begin{array}{l}\text { Model } \\
\text { reologiczny }\end{array}$} & \multirow{2}{*}{$\begin{array}{l}\text { Parametry } \\
\text { reologiczne }\end{array}$} & \multicolumn{8}{|c|}{ Numer zaczynu } \\
\hline & & $1 \mathrm{baz}$ & 2 & 3 & 4 & $5 \mathrm{baz}$ & 6 & 7 & 8 \\
\hline \multirow{3}{*}{$\begin{array}{l}\text { Model } \\
\text { Binghama }\end{array}$} & $\begin{array}{c}\text { Lepkość plastyczna } \\
{[\mathrm{Pa} \cdot \mathrm{s}]}\end{array}$ & 0,0843 & 0,0744 & 0,0725 & 0,0673 & 0,0843 & 0,0826 & 0,0870 & 0,0808 \\
\hline & $\begin{array}{c}\text { Granica płynięcia } \\
{[\mathrm{Pa}]}\end{array}$ & 3,7329 & 1,4737 & 1,8008 & 1,6682 & 3,7329 & 8,9082 & 10,8413 & 14,8805 \\
\hline & $\begin{array}{l}\text { Współczynnik korelacji } \\
{[-]}\end{array}$ & 0,9985 & 0,9994 & 0,9985 & 0,9993 & 0,9985 & 0,9963 & 0,99322 & 0,9800 \\
\hline \multirow{3}{*}{$\begin{array}{c}\text { Model } \\
\text { Ostwalda } \\
\text { de Waele'a }\end{array}$} & $\begin{array}{l}\text { Współczynnik konsystencji } \\
{\left[\mathrm{Pa} \cdot \mathrm{s}^{\mathrm{n}}\right]}\end{array}$ & 1,2052 & 0,3201 & 0,4050 & 0,4370 & 1,2052 & 3,5122 & 4,1276 & 5,4142 \\
\hline & $\begin{array}{c}\text { Wykładnik potęgowy } \\
{[-]}\end{array}$ & 0,5633 & 0,7637 & 0,7172 & 0,6895 & 0,5633 & 0,4160 & 0,4084 & 0,3819 \\
\hline & $\begin{array}{c}\text { Współczynnik korelacji } \\
{[-]}\end{array}$ & 0,9375 & 0,9843 & 0,9738 & 0,9636 & 0,9375 & 0,9353 & 0,9498 & 0,9768 \\
\hline \multirow{3}{*}{$\begin{array}{c}\text { Model } \\
\text { Cassona }\end{array}$} & $\begin{array}{c}\text { Lepkość Cassona } \\
{[\mathrm{Pa} \cdot \mathrm{s}]}\end{array}$ & 0,0659 & 0,0669 & 0,0644 & 0,0583 & 0,0659 & 0,0517 & 0,0536 & 0,0461 \\
\hline & $\begin{array}{c}\text { Granica płynięcia } \\
{[\mathrm{Pa}]}\end{array}$ & 1,2902 & 0,2522 & 0,3334 & 0,3728 & 1,2902 & 4,7172 & 5,8097 & 8,5638 \\
\hline & $\begin{array}{c}\text { Współczynnik korelacji } \\
{[-]}\end{array}$ & 0,9999 & 0,9999 & 0,9997 & 1,0000 & 0,9999 & 0,9994 & 0,9996 & 0,9947 \\
\hline \multirow{4}{*}{$\begin{array}{c}\text { Model } \\
\text { Herschela- } \\
\text { Bulkleya }\end{array}$} & $\begin{array}{c}\text { Granica płynięcia } \\
{[\mathrm{Pa}]}\end{array}$ & 2,2990 & 0,7407 & 0,5749 & 0,9196 & 2,2990 & 6,7047 & 7,3860 & 8,4884 \\
\hline & $\begin{array}{c}\text { Współczynnik konsystencji } \\
{\left[\mathrm{Pa} \cdot \mathrm{s}^{\mathrm{n}}\right]}\end{array}$ & 0,1849 & 0,1204 & 0,1583 & 0,1152 & 0,1849 & 0,2605 & 0,4173 & 0,9992 \\
\hline & $\begin{array}{c}\text { Wykładnik potęgowy } \\
{[-]}\end{array}$ & 0,8857 & 0,9299 & 0,8862 & 0,9217 & 0,8857 & 0,8330 & 0,7725 & 0,6365 \\
\hline & $\begin{array}{c}\text { Współczynnik korelacji } \\
{[-]}\end{array}$ & 1,0000 & 0,9999 & 1,0000 & 0,9999 & 1,0000 & 0,9994 & 0,9993 & 0,9956 \\
\hline
\end{tabular}

*Wyróżnieniem zaznaczono model reologiczny o najwyższym współczynniku korelacji Pearsona. 
Rozpatrując wpływ dodatku lignosulfonianu na parametry reologiczne zaczynu cementowego, zaobserwowano obniżenie wartości granicy płynięcia po zastosowaniu tego dodatku. Zaczyn bazowy nr 1 posiadał wartość granicy płynięcia opisywanej modelem Cassona równą 1,29 $\mathrm{Pa}$, wprowadzenie dodatku 0,1\% (bwoc) opóźniacza spowodowało obniżenie granicy płynięcia do wartości $0,25 \mathrm{~Pa}$. Kolejne wzrastające ilości opóźniacza powodowały niewielki wzrost granicy płynięcia, jednakże przy maksymalnej ze stosowanych ilości opóźniacza $(0,3 \%$ (bwoc) ) granica płynięcia, wynosząca 0,37 Pa w zaczynie $\mathrm{nr} 4$, nie przekroczyła wartości bazowej. Porównywalny trend zmiany wartości granicy płynięcia obserwowany był podczas interpretacji modelu reologicznego Herschela-Bulkleya, gdzie najmniejsza (0,1-procentowa w stosunku do masy cementu) ilość opóźniacza spowodowała najmocniejsze obniżenie granicy płynięcia (z wartości 2,29 Pa dla zaczynu bazowego $\mathrm{nr} 1$ do wartości $0,74 \mathrm{~Pa}$ w zaczynie zawierającym $0,1 \%$ opóźniacza), natomiast kolejne wzrastające ilości dodatku opóźniającego powodowały wzrost granicy płynięcia, który w końcowym etapie nie przekroczył wartości bazowej. Dodatek środka opóźniającego powoduje również obniżenie współczynnika konsystencji opisywanego modelem Herschela-Bulkleya. Zaczyn kontrolny (nr 1) posiadał współczynnik konsystencji $\mathrm{HB}_{\mathrm{HB}}$ równy $0,1849 \mathrm{~Pa} \cdot \mathrm{s}^{\mathrm{n}}$ natomiast obecność lignosulfonianu w zaczynie cementowym powodowała obniżenie wartości tego współczynnika do wartości z zakresu od $0,1152 \mathrm{~Pa} \cdot \mathrm{s}^{\mathrm{n}}$ do $0,1583 \mathrm{~Pa} \cdot \mathrm{s}^{\mathrm{n}}$. Analizując uzyskane wyniki parametrów reologicznych, nie stwierdzono wyraźnego wpływu dodatku lignosulfonianu na lepkość opisywaną modelem reologicznym Cassona. Powyżej omówione wyniki badań zestawiono w tablicy 4 oraz na rysunku 5.

Stosowany do skrócenia czasu wiązania chlorek wapnia powodował z kolei odmienne zmiany parametrów reologicznych niż dodatek lignosulfonianu. Wartość granicy płynięcia opisywana modelem Cassona wzrosła z 1,29 $\mathrm{Pa}$ (zaczyn bazowy nr 5) do wartości 8,56 Pa dla zaczynu z dodatkiem $3 \% \mathrm{CaCl}_{2}$. Również granica płynięcia opisywana modelem Herschela-Bulkleya charakteryzowała się porównywalnym trendem wzrostowym, przy czym największy wzrost wartości uzyskano już po wprowadzeniu $1 \%$ chlorku wapnia do zaczynu, a kolejne wzrastające ilości powodowały dalszy wzrost granicy płynięcia (rysunek 5). Obecność dodatku chlorku wapnia w zaczynie cementowym powodowała wzrost współczynnika konsysten$\mathrm{cji}_{\mathrm{HB}}$. Wraz ze zwiększaniem dodatku $\mathrm{CaCl}_{2}$ wzrastał współczynnik konsystencji Herschela-Bulkleya, osiągając wartość maksymalną wynoszącą $0,9992 \mathrm{~Pa} \cdot \mathrm{s}^{\mathrm{n}} \mathrm{w}$ przypadku zastosowania 3\% chlorku wapnia - w porównaniu do współczynnika konsystencji równego $0,1846 \mathrm{~Pa} \cdot \mathrm{s}^{\mathrm{n}}$ uzyskanego dla zaczynu kontrolnego (bez dodatku chloru wapnia). Dodatek przyspieszacza w postaci chlorku wapnia powodował obniżenie wartości lepkości Cassona (lepkośćc Css ), która w zaczynie bazowym wynosiła $0,0659 \mathrm{~Pa} \cdot \mathrm{s}$, natomiast $\mathrm{w}$ zaczynie $\mathrm{z}$ dodatkiem 3\% $\mathrm{CaCl}_{2}$ (bwoc) miała wartość 0,0461 Pa.s. Zestawienie oraz interpretację graficzną omawianych wyników badań przedstawiono w tablicy 4 oraz na rysunku 5 .

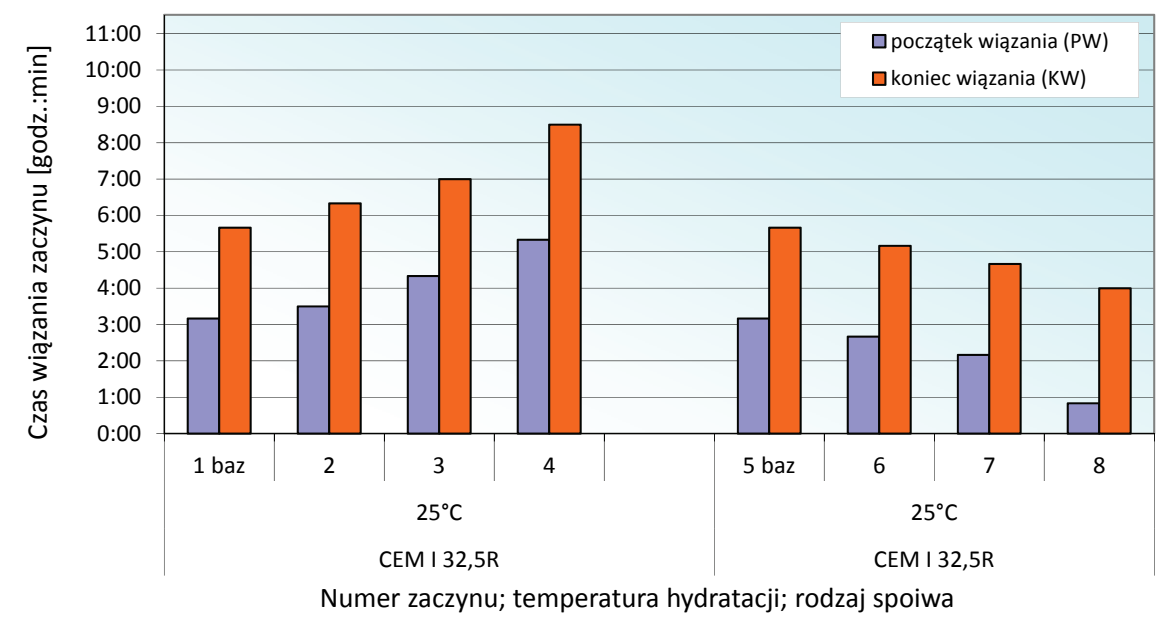

Rys. 4. Zestawienie pomiarów czasu wiązania zaczynów cementowych

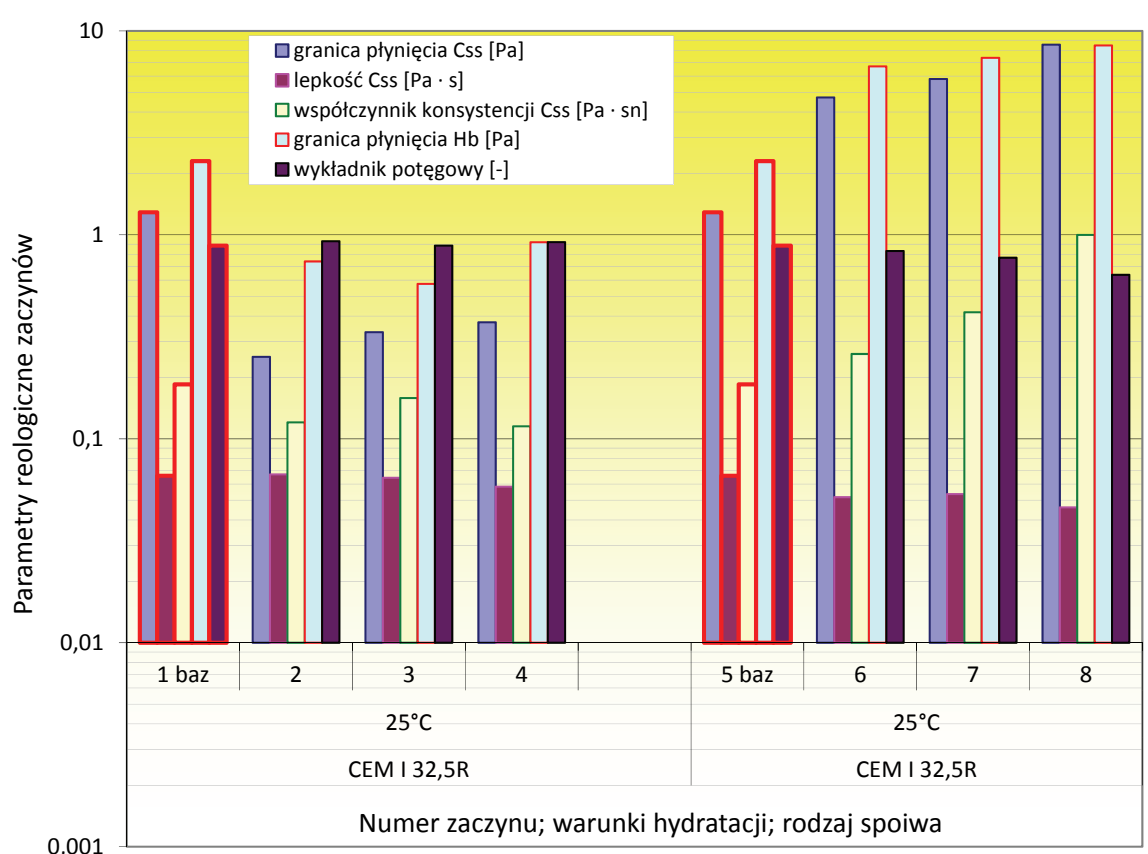

Rys. 5. Zestawienie wybranych wyników badań parametrów reologicznych zaczynów cementowych 
W celu dokładniejszej analizy parametrów reologicznych i określenia wpływu dodatków regulujących czas wiązania na te parametry sporządzone zostały wykresy obrazujące przebieg krzywych płynięcia dla badanych zaczynów.

Analizując przebieg zależności naprężeń stycznych od gradientu prędkości, czyli prędkości ścinania, można zauważyć obniżanie się lepkości dynamicznej zaczynu wraz ze wzrostem dodatku lignosulfonianu w zakresie od $0,1 \%$ do $0,3 \%$. Zaobserwować to można na podstawie nachylenia krzywych (rysunek 6), czyli zmniejszającego się ich tangensa kąta, który się tworzy $\mathrm{z}$ linią odciętych. Powyższe znajduje niejako potwierdzenie we wcześniejszych badaniach parametrów reologicznych, w których zarówno wartości lepkości Cassona, jak też lepkość plastyczna opisywana modelem Binghama ulegały obniżeniu wskutek wzrastającej ilości lignosulfonianu w zaczynie cementowym.

Odwrotna sytuacja ma miejsce podczas interpretacji krzywych płynięcia dla zaczynów z dodatkiem przyspieszacza w postaci chlorku wapnia (rysunek 7). Krzywa dla zaczynu bazowego przebiega najniżej i receptura tego zaczynu posiada najniższą wartość lepkości dynamicznej, natomiast wraz ze wzrostem dodatku $\mathrm{CaCl}_{2}$ w zakresie od $1 \%$ do $3 \%$ obserwowany jest niewielki wzrost lepkości, przejawiający się coraz mniejszym nachyleniem krzywych.

Analiza przebiegu krzywych płynięcia uwidacznia znaczny wzrost naprężeń ścinających przy niskich wartościach szybkości ścinania w przypadku zaczynów z dodatkiem chlorku wapnia. Taki przebieg krzywych potwierdzać może tiksotropowy charakter zaczynów cementowych, które posiadają wysokie wartości granicy płynięcia oraz wytrzymałości strukturalnej. W przypadku zaczynów z dodatkiem środka opóźniającego w postaci lignosulfonianu obserwuje się zbliżone wartości naprężeń ścinających przy niskich szybkościach ścinania, co również potwierdza niskie wartości parametrów reologicznych tej grupy zaczynów.

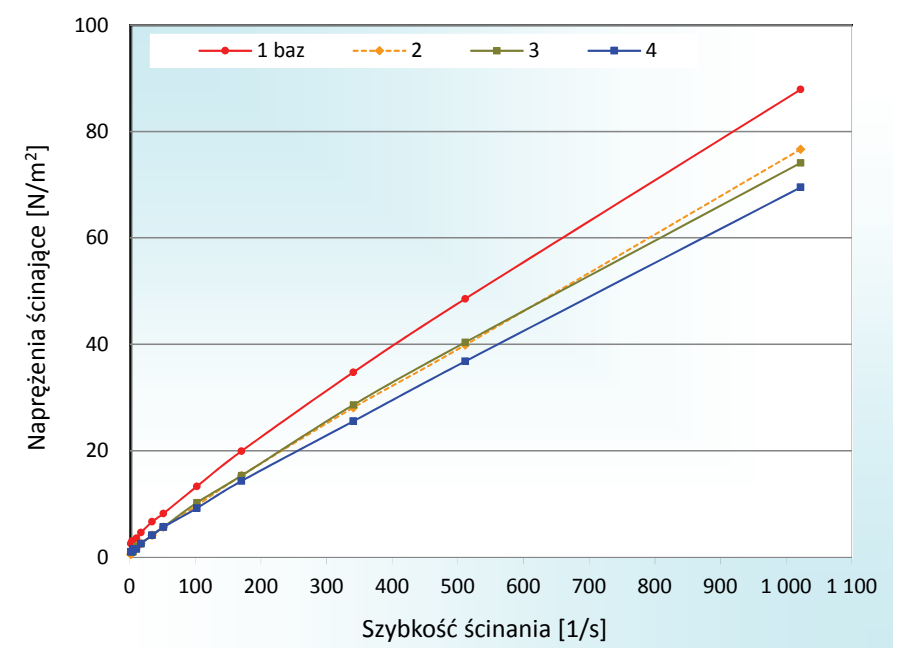

Rys. 6. Przebieg krzywych płynięcia dla zaczynów z dodatkiem środka opóźniającego czas wiązania
Podsumowując powyższe rozważania dotyczące wpływu dodatków środków regulujących czas wiązania zaczynu na parametry reologiczne, stwierdzono, że istnieje ścisła zależność pomiędzy omawianymi cechami. Przeprowadzone badania jednoznacznie potwierdzają, że badany dodatek środka opóźniającego czas wiązania powoduje obniżenie parametrów reologicznych, tj. granicy płynięcia opisywanej zarówno modelem Cassona, jak i Herschela-Bulkleya, współczynnika konsystencji oraz obserwowanych na wykresach krzywych płynięcia lepkości dynamicznych. Takie zachowanie dodatku opóźniającego czas wiązania wykazuje działanie dyspergujące. Zaczyn z dodatkiem lignosulfonianu ulega upłynnieniu, co może mieć negatywny wpływ na stabilność sedymentacyjną opracowywanego składu. Powyższe należy mieć na uwadze podczas projektowania receptury i odpowiednio zmodyfikować skład w celu wyeliminowania tego niepożądanego zjawiska.

Z kolei dodatek środków przyspieszających wiązanie zaczynu, spośród których głównym tego rodzaju dodatkiem jest chlorek wapnia, powoduje mocny wzrost parametrów reologicznych zaczynu. Obserwowane jest niejako odwrotne działanie - nie tylko w samym mechanizmie, czyli przyspieszeniu reakcji hydratacji, ale również podczas interpretacji parametrów reologicznych. Taki wpływ chlorku wapnia należy również mieć na uwadze podczas projektowania zaczynu. Zbyt duży wzrost parametrów reologicznych, objawiający się mocnym żelowaniem zaczynu, może powodować rozszczelinowanie strefy złożowej podczas tłoczenia zaczynu, ponieważ w celu uzyskania odpowiedniej prędkości przepływu wymagane będzie wytworzenie większego ciśnienia tłoczenia. Pozytywnym aspektem stosowania zaczynów z dodatkiem przyspieszacza wiązania jest fakt, że receptury te wykazują znaczną stabilność sedymentacyjną z uwagi na wysokie wartości granicy płynięcia i wytrzymałości strukturalnej.

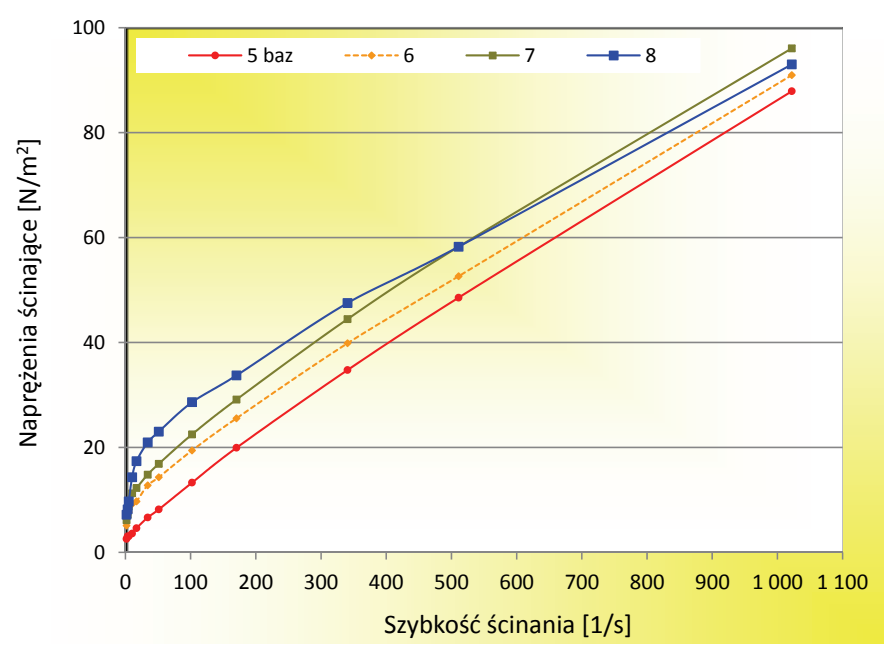

Rys. 7. Przebieg krzywych płynięcia dla zaczynów $\mathrm{z}$ dodatkiem środka przyspieszającego wiązanie 


\section{Wnioski}

Na podstawie uzyskanych wyników badań stwierdzono, co następuje:

1. Zarówno dodatki opóźniające wiązanie zaczynu, jak i środki przyspieszające wiązanie wykazują wpływ na parametry reologiczne sporządzanego zaczynu cementowego.

2. Środki opóźniające wiązanie zaczynu cementowego powodują obniżenie parametrów reologicznych takich jak: granica płynięcia opisywana modelem Cassona, granica płynięcia opisywana modelem Herschela-Bulkleya, współczynnik konsystencji oraz lepkość dynamiczna.

3. Ze względu na obniżenie parametrów reologicznych przez środki opóźniające można je zaliczyć do grupy środków wykazujących działania dyspergujące.

4. Podczas stosowania opóźniaczy wiązania należy mieć na uwadze ewentualność utraty stabilności sedymentacyjnej zaczynu cementowego i poczynić odpowiednie działania w celu zapobieżenia temu zjawisku.

5. Dodatki przyspieszające wiązanie zaczynu cementowego powodują wzrost parametrów reologicznych takich jak granica płynięcia opisywana modelem Cassona, wzrost lepkości dynamicznej oraz nieznaczne obniżenie lepkości plastycznej opisywanej modelem Cassona.

6. Stosowanie środków przyspieszających wiązanie zaczynu cementowego pozwala na poprawę stabilności sedymentacyjnej zaczynu.

7. Podczas stosowania środków przyspieszających wiązanie zaczynu cementowego należy mieć na uwadze znaczny wzrost wartości parametrów reologicznych i w związku z powyższym podejmować odpowiednie czynności w celu zachowania wymaganych ich wartości.

Prosimy cytować jako: Nafta-Gaz 2018, nr 11, s. 828-838, DOI: 10.18668/NG.2018.11.07

Artykuł nadesłano do Redakcji 2.09.2018 r. Zatwierdzono do druku 24.10.2018 r.

Artykuł powstał na podstawie pracy badawczej pt.: Analiza możliwości poprawy wczesnej wytrzymałości mechanicznej płaszcza cementowego z zaczynów lekkich - praca INiG - PIB na zlecenie MNiSW; nr zlecenia: 14/KW/18, nr archiwalny: DK-4100/14/18.

\section{Literatura}

[1] Bensted J.: Effect of Accelerator Additives on the Early Hydration of Portland Cement. Il Cemento 1978, vol. 75, s. 13-20.

[2] Bruere G.M.: Set-Retarding Effects of Sugars in Portland Cement Pastes. Nature 1966, vol. 212, s. 502-503.

[3] Collepardi M.: Il Comportamento Reologico delle Paste Cementizie. II Cemento 1971, vol. 68, s. 99-106.

[4] Gonet A., Stryczek S.: Reologia wybranych zaczynów uszczelniajacych wykonanych z cementów Górażdze Cement S.A. Sympozjum Naukowo-Techniczne „Cementy w budownictwie, robotach wiertniczych i inżynieryjnych oraz hydrotechnice”, Piła-Płotki 2001.

[5] Jawed I., Klemm W.A., Skalny J.: Hydration of cement-Lignosulfonate-Alkali Carbonate System. J. Amer. Ceramic. Soc. 1979, vol. 62, s. 461-464.

[6] Jennings H.M., Taleb H., Frohnsdorff G., Clifton J.R.: Interpretation of the Effect of Retarding Admixtures on Pastes of $\mathrm{C}_{3} \mathrm{~S} \mathrm{C}_{3} \mathrm{~A}$ Plus Gypsum and Portland Cement. Proceedings of the Eight International Congress on the Chemistry of Cement, Rio de Janeiro, Brazil, September 22-27, 1986, s. 239-243.

[7] Kremieniewski M.: Modyfikacja przestrzeni porowej kamieni cementowych. Nafta-Gaz 2012, nr 3, s. 165-170.

[8] Kremieniewski M.: Ograniczenie ekshalacji gazu w otworach wiertniczych poprzez modyfikacje receptur oraz ksztattowanie się struktury stwardniałych zaczynów uszczelniajacych. Prace Instytutu Nafty i Gazu - PIB 2016, nr 199, s. 1-400, DOI: 10.18668/PN2016.199.

[9] Kremieniewski M.: Poprawa wczesnej wytrzymałości mechanicznej płaszcza cementowego powstałego z zaczynu lekkiego. Nafta Gaz 2018, nr 8, s. 599-605, DOI: 10.18668/ NG.2018.08.06.

[10] Kremieniewski M.: Wptyw dodatku superplastyfikatora na zwiększenie efektywności uszczelniania kolumn rur okładzinowych. Nafta-Gaz 2016, nr 3, s. 169-176.
[11] Kremieniewski M., Rzepka M.: Celowość prowadzenie prac badawczych nad nowymi środkami obniżajacymi filtrację zaczynów cementowych. Nafta-Gaz 2017, nr 8, s. 583-590, DOI: 10.18668/NG.2017.08.05.

[12] Kremieniewski M., Rzepka M.: Poprawa szczelności płaszcza cementowego za pomoca innowacyjnych dodatków antymigracyjnych. Nafta-Gaz 2018, nr 6, s. 8-15, DOI: 10.18668/ NG.2018.06.06.

[13] Kremieniewski M., Rzepka M., Stryczek S., Wiśniowski R., Kotwica Ł., Złotkowski A.: Korelacja przepuszczalności i parametrów opisujących strukturę stwardniatych zaczynów cementowych stosowanych do uszczelniania otworów $w$ rejonie Basenu Pomorskiego. Nafta-Gaz 2015, nr 10, s. 737-746, DOI: 10.18668/NG2015.10.04.

[14] Kremieniewski M., Stryczek S., Kotwica Ł.: Zmiany w mikrostrukturze płaszcza cementowego w zależności od warunków hydratacji zaczynu. Nafta-Gaz 2014, nr 12, s. 918-926.

[15] Kurczyk H.G., Schwiete H.E.: Elektronenmikroskopische und Thermochemische Untersuchungen über die Hydration der Calciumsilikate $3 \mathrm{CaO} \cdot \mathrm{SiO}_{2}$ und $\beta \cdot 2 \mathrm{CaO} \cdot \mathrm{SiO}_{2}$ und den Einflub von Calciumchlorid und Gips auf den Hydrationsvorgang. Tonind-Zeit und Keramische Rundsch. 1960, vol. 24, s. 585-597.

[16] Małolepszy J., Wójcik J.: Wpływ dodatków chemicznych na procesy hydratacji genelitu. Cz. I. Cement-Wapno-Gips 1987, nr 6, s. 114-118.

[17] Michaux M., Fletcher P., Vidick B.: Evolution at Early Hydration Times of the Chemical Composition of Liquid Phase of Oilwell Cement Pastes With and Without Additives. Cement and Concrete Res. 1989, vol. 19, s. 443-456.

[18] Milestone N.B.: The Effect of Lignosulphonate Fractions on the Hydration of Tricalcium Aluminate. Cement and Concrete Res. 1976, vol. 6, s. 89-102. 
[19] Nelson E.B., Guillot D.: Well Cementing. Schlumberger 2006.

[20] Odler I., Duckseint U., Becker T.: On the Combined Effect of Water Soluble Lignosulfonates and Carbonates on Portland Cement and Clinker Pastes - Pt. 1: Physical Properties. Cement and Concrete Res. 1978, vol. 8. s. 469-479.

[21] Older I., Skalny J.: Influence of Calcium Chloride on Paste Hydration of Tricalcium Silicate. J. Amer. Ceramic Soc. 1971, vol. 54, s. 362-363.

[22] Rzepka M., Stryczek S.: Laboratoryjne metody określania parametrów technologicznych świeżych zaczynów uszczelniajacych przed zabiegiem zwiazanym z procesem uszczelniania kolumn rur okladzinowych $w$ otworach wiertniczych. Wiertnictwo, Nafta, Gaz 2008, nr 25/2, s. 625-636.

[23] Skalny J., Maycock J.N.: Mechanisms of Acceleration by Calcium Chloride: A Review. J. Testing and Evaluation 1975, vol. 3, nr 4, s. 303-3011.

[24] Stryczek S.: Wpływ superplastyfikatorów na właściwości reologiczne zaczynów cementowych. Nowoczesne Budownictwo Inżynieryjne 2011, s. 60-62.

[25] Stryczek S., Wiśniowski R., Gonet A., Ferens W.: Parametry reologiczne świeżych zaczynów uszczelniajacych w zależności od czasu ich sporzadzania. Wiertnictwo, Nafta, Gaz 2009, nr 26/1-2, s. 369-382.

[26] Stryczek S., Wiśniowski R., Gonet A., Złotkowski A.: The influence of time of rheological parameters of fresh cement slurries. AGH Drilling, Oil, Gas 2014, vol. 31, nr 1, s. 123-133.

[27] Stryczek S., Wiśniowski R., Kumala B.: Wpływ superplastyfikatora na parametry technologiczne zaczynów uszczelniajacych sporzadzonych na osnowie cementów portlandzko popiotowych. Wiertnictwo, Nafta, Gaz 2008, nr 25/2, s. 717-731.

[28] Taplin J.H.: Discussion of Some Chemical Additives and Ad- mixures in Cement Paste and Concrete. Proc. Fourth Intl. Cong. Chem. Cement, Washington 1960, vol. 2, s. 924.

[29] Traettebert A., Grattan-Bellew P.E.: Hydration of $3 \mathrm{CaO} \cdot \mathrm{Al}_{2} \mathrm{O}_{3}$ and $3 \mathrm{CaO} \cdot \mathrm{Al}_{2} \mathrm{O}_{3}+$ Gypsum With and Without $\mathrm{CaCl}_{2}$. J. Amer. Ceramic Soc. 1975, vol. 58, s. 221-227.

[30] Wiśniowski R.: O oporach przepływu cieczy wiertniczych. Wiertnictwo, Nafta, Gaz 2003, nr 20/2, s. 441-455.

[31] Wiśniowski R., Stryczek S., Skrzypaszek K.: Kierunki rozwoju badań nad reologia płynów wiertniczych. Wiertnictwo, Nafta, Gaz 2007, nr 24, s. 595-607.Wiśniowski R., Stryczek S., Skrzypaszek K.: Wyznaczanie oporów laminarnego przepływu zaczynów cementowych, opisywanych modelem Herschela-Bulkleya. Wiertnictwo, Nafta, Gaz 2006, nr 23/1, s. 533-542.

[32] Young J.F., Berger R.L., Lawrence Jr. F.V.: Studies on the Hydration of Tricalcium Silicate Pastes - Pt. 3: Influence of Admixtures on Hydration and Strength Development. Cement and Concrete Res. 1973, vol. 3, no. 6, s. 689-700.

\section{Akty prawne i normatywne}

[33] PN-EN ISO 10426-2 Przemyst naftowy i gazowniczy - Cementy i materiały do cementowania otworów - część 2: Badania cementów wiertniczych.

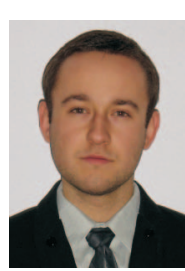

Dr inż. Marcin KREMIENIEWSKI

Adiunkt w Zakładzie Technologii Wiercenia

Instytut Nafty i Gazu - Państwowy Instytut Badawczy ul. Lubicz 25 A

31-503 Kraków

E-mail:marcin.kremieniewski@inig.pl

\section{OFERTA}

\section{ZAKŁAD TECHNOLOGII WIERCENIA}

Zakres działania:

- opracowywanie składów i technologii sporządzania płuczek wiertniczych, cieczy do dowiercania, opróbowania i rekonstrukcji odwiertów, zaczynów cementowych i mieszanin wiążących dla różnych warunków geologiczno-technicznych wiercenia;

- $\quad$ kompleksowe badania i ocena nowych rodzajów środków chemicznych, materiałów płuczkowych i wiążących, przeznaczonych do sporządzania i regulowania właściwości płuczek wiertniczych i zaczynów cementowych;

- $\quad$ pomiary parametrów technologicznych cieczy wiertniczych i kamienia cementowego w warunkach normalnej i wysokiej temperatury oraz ciśnienia;

- $\quad$ badania wpływu płuczek wiertniczych na przewiercane skały;

- dobór płuczek wiertniczych, zaczynów cementowych, cieczy buforowych w celu poprawy skuteczności cementowania otworów wiertniczych;

- $\quad$ badania serwisowe dla bieżacych zabiegów cementowania;

- $\quad$ specjalistyczne badania laboratoryjne dotyczące oznaczania: współczynnika tarcia cieczy wiertniczych i napięcia powierzchniowego na granicy faz, czystości i temperatury krystalizacji solanek, typu emulsji, sedymentacji fazy stałej, efektywności wynoszenia zwiercin w otworach kierunkowych i poziomych oraz wypłukiwania osadów iłowych ze skał przed zabiegiem cementowania, odporności na migrację gazu w wiążącym zaczynie cementowym w warunkach otworopodobnych, wczesnej wytrzymałości na ściskanie kamienia cementowego, odporności korozyjnej kamienia cementowego w różnym środowisku złożowym, porowatości oraz przepuszczalności dla gazu kamienia cementowego i skał, zawartości związków chemicznych w cieczach wiertniczych, stopnia toksyczności środków chemicznych i cieczy wiertniczych przy użyciu bakterii bioindykatorów;

- $\quad$ badania właściwości fizyczno-mechanicznych skał pod kątem ich zwiercalności.

Kierownik: dr inż. Małgorzata Uliasz

Adres: ul. Armii Krajowej 3, 38-400 Krosno

Telefon: 134368941 w. 5219

Faks: 134367971

E-mail: malgorzata.uliasz@inig.pl

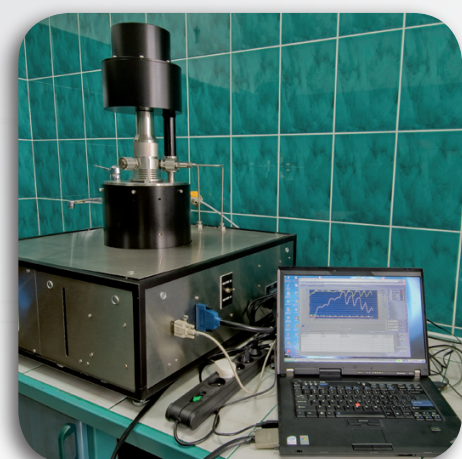

